\title{
共通講習 (医療安全)
}

\section{医療安全の基本}

\section{はじめに}

6年前から耳鼻咽喉科・頭頸部外科医と医師GRM（ゼ ネラルリスクマネジャー）という二足の草鞋を履いてき た者として，医療安全活動の現場から見た医療安全の基 本を整理してみたい。

\section{1. 基本的な用語について}

医療安全関係の用語は特殊なものもある。特に「医療 事故」という用語は厄介である。使う人の立場, 場面, 文脈によって様々な意味で使用される。マスメディアで 「医療事故」と言えば, 医療者の過失を前提とした場合が 多いが，医療安全分野では，しばしば過失の有無を問わ ない。これからの議論で誤解を生じないように, 図1に 医療事故にまつわる用語（旭川医科大学編）を扮示しす る。この定義は, 医療安全用語辞典2004年版に基づいて,

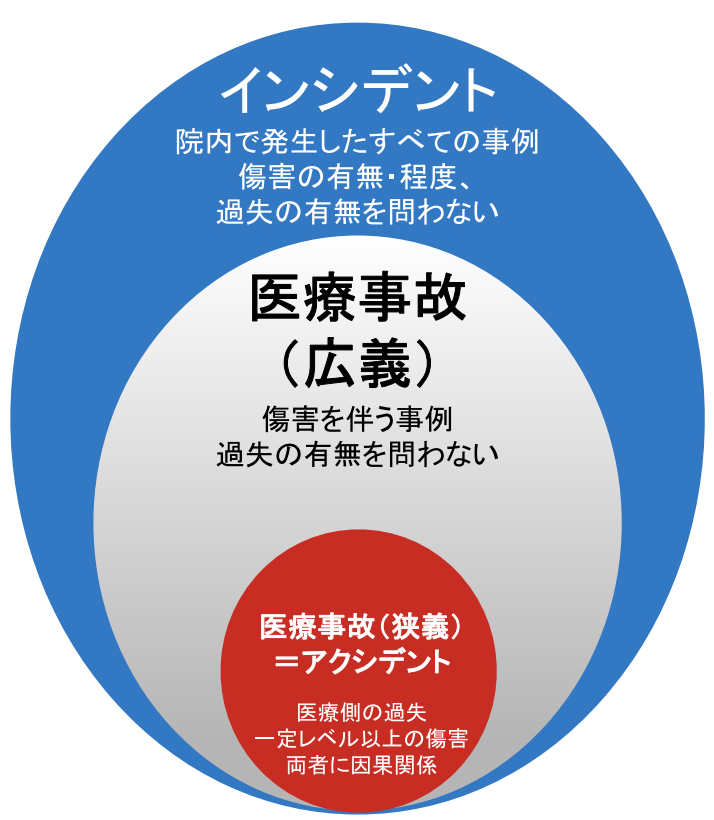

図1 インシデントと医療事故の概念図

\author{
林達哉 \\ 旭川医科大学耳鼻咽喉科・頭頸部外科 \\ 頭頸部癌先端的診断·治療学講座 \\ 医療安全管理部 専任リスクマネジャー(医師GRM)
}

旭川医科大学の医療安全活動を行う上で不都合がないよ うに決定されたものである。唯一無二の定義ではないが, 他の文脈でこれらの用語をご覧になった際に，何を意味 するかを推測するヒントになるはずである。

\section{2. 歴史を知る}

本邦で医療安全管理体制の整備が叫ばれたのは，いく つかの歴史的医療事故がきっかけだった。新しい世紀を 前に， 20 世紀の沈殿物が一気に吹き出した感があった。 これらの事例は「医療事故はどのようにして起こるの か」，「再発防止策はどのように現在の医療に生きている のか」を雄弁に物語ってくれる。私たちは同じ過ちを経 験する危険をおかすことも，代償としてのコストを支払 うこともなく，貴重な経験を手にすることができる。

歴史的事例 1

概要：1999年1月 横浜市立大学付属病院で肺手術と心 臟手術予定患者を取り違えて手術。

経過： 2 人の患者を 2 台のストレッチャーに乗せ, 病棟 の看護師 1 人で手術室に搬送した。手術室看護師は 2 名の 患者を誤認し, 患者Aに「Bさん」, 患者Bに「Aさん」と 呼びかけた。患者 $\mathrm{A}$, 患者Bから訂正はなく, 会話が成立 した。執刀医は疑問を感じながらも，患者確認を行わず に手術を開始した。手術終了後ICUの看護師が患者の取 り違えを発見した ${ }^{1}$ 。

要因と対策：患者確認は患者自身に名乗ってもらうのが 現在の基本である。この現在の基本（常識）が形作られ るきっかけの一つとなったのが本事例である。執刀前の タイムアウトも実施されていなかった。WHOが手術 チェックリストを推奨したのが2009年，NHKがチェック リストを主題にした「ER」を放送したのが2011年 2 月 だった。この直後, チェックリストを含むタイムアウト が全国の病院に一気に普及することになった。 
歴史的事例 2

概要：1999年 2 月都立広尾病院で点滴後に患者が死亡し た。原因は看護師が点滴ルートに消毒液ヒビテングルコ ネートを注入したことだった。看護師はへパリン生食の 入ったシリンジを処置台の上に用意した。これを片づけ ることなく，同じ処置台上で同形シリンジに創処置用の ヒビテングルコネートを置き, その後シリンジの取り違 えが発生したものと推測された ${ }^{2)}$ 。

要因と対策 : 消毒液が静注用のシリンジに用意され, 点 滴ルートに接続可能だった。静注用と非静注用のシリン ジの先端の形状を変え, 非静注用シリンジは静脈ルート に接続できない様にすれば，たとえ「ワナ」が仕掛けら れたとしても失敗はできない。この様に間違えることが 難しい仕組みを「fool proof」と呼び, シリンジや医療用 ガスコネクタで実用化されている。

\section{歴史的事例 3}

概要: 2000 年 2 月, 京都大学病院にて人工呼吸器の加湿 器に精製水と間違えてエタノールを注入し患者が中毒死 しだ)。

要因と対策 : 加湿器に使用する精製水は, ポリタンクに 入って流しの下に置かれていた。消毒用のエタノールも 同じく流しの下に, 同形, 同色のポリタンクに入った状 態で置かれていた。

対策：パック入り酒精綿, 分包化された酒精綿を導入 する。酒精綿作製用の多量のエタノールを病棟に置く必 要がなくなり, 流しの下の「ワナ」を葬り去ることがで きた。

\section{3. インシデントレポート}

\section{1）報告制度の目的}

歴史的事例から明らかなのは，医療の現場には誰もが 嵌まる危険のある多くの「ワナ」が隠されているという 事実である。これを放置したまま，患者の安全と良質な 医療の両立を図るのは難しい。日常の医療プロセスから 「ワナ」を発見し消滅させる, あるいは無力化するのが医 療安全の大きな使命である。そのための貴重な材料を提 供してくれるのが, インシデントレポートである。300 の軽微なインシデントを研究し, めったに起きない $1 つ$ の重大な医療事故=アクシデントを防ぐのである。

\section{2）だれのための報告制度か}

とは言っても，インシデントレポートは喜んで入力す るような種類のものではない。自分の失敗（エラー）を 他人の目に曝して気分が良いはずがない。忙しい医療の
中で報告にあてる時間も惜しい。そもそも何のための報 告なのか。このように報告する上で,いくつもの心的ハー ドルが存在する。そこで一度見方を変えるために, イン シデントレポートは誰のためにあるのか, という視点で 考えることをお勧めする。インシデントレポートは(1)患 者のため：安全な医療は患者が医療を受ける大前提であ る，(2病院のため：安全な医療が提供できない病院は選 ばれない，(3)高度な医療技術のため：高度な医療を推進 するための透明性確保に資する，(4)同僚や後輩のため： 報告をもとに実現した対策によって, 将来のインシデン 卜，医療事故を防ぐことができる，そしてもう一つ大事 なのが，5報告者自身のためという視点である。インシ デントレポートで報告された事例は, 医療安全管理部 (名 称は施設によって異なる）を通して病院の案件となる。 事故ではないと判定されれば, 病院のお墨付きを得たこ とになる。不幸にして患者側の理解を得られずに医療訴 訟に発展した場合でも, 判断の責任は病院が負う。自分 の判断で報告しなかった場合, あるいは重大なインシデ ントあるいはアクシデントを意図的に報告しなかった場 合，後に明らかとなれば，隠蔽として個人の責任が問わ れかねない。病院が契約する保険の場合, 保険会社が最 初に行ういくつかの確認事項の中に, インシデント報告 の有無を問う項目もあるのが一般的である。レポートが ないことは，不利に働くと考えておいた方がよい。

\section{3）レポートの開示請求は拒否できる}

インシデントレポートそのものは, たとえ裁判所から 開示を請求されても拒むことができる。総務省の情報公 開・個人情報保護審査会においてもこれを支持する結論 が得られている(平成 15 年度答申第 267 号及び同 268 号)。 これは，再発防止策の立案による医療安全の向上を目的 とするインシデント報告制度の根幹に関わる問題だから である。非公開を前提に作成されたレポートが公開され れば，報告者の不利益に繋がりかねない。報告者が疑念 を抱けば, レポートの収集は困難に陥り, 報告制度その ものが立ちゆかなくなってしまうのである。

どうか, 安心して報告し, 医療安全活動に参加してい ただきたい。患者のために, 同僚・後輩のために, そし て自分自身のためにも。

\section{4. 画像診断報告書にまつわる問題}

昨今，世間を摇るがす医療安全上の大問題が新聞紙面 を賑わしている。ご存じの通り，画像診断レポートの見 落とし事例である。患者や患者家族にとって,「絶対に起 こるはずのない, あってはならない事態」であるのは当 
然である。一方で多くの医師が，他人事ではないと直感 したはずである。

未読は(1)真の未読，すなわちレポートを確認していな い場合と，(2)患者への未通知に分類される。いずれも， カルテ電子化の負の側面が否定できない。詳細を記すこ とは紙幅の都合でできないが，紙運用であった頃と比較 分析することにより，解決のヒントが見えてくる。それ ぞれの，医療施設の実情に即した，システム構築と運用 の見直しの両面からの解決策が望まれる。

\section{おわりに}

旭川医科大学では医療安全管理部長も医師GRMの一 人 (筆者) も耳鼻咽喉科医である。このため未読問題の 解決活動の中心を耳鼻咽喉科医が担うという状況が生ま れた。これは特殊な状況かもしれないが，この課題も含 め, 医療安全の多くは耳鼻咽喉科医療にも大きく関係す ることは日々害感している。インシデントレポートの項
目でも述べた様に，誰のための仕組みかを考え，主体的 に医療安全活動に参加していただければと願ってやま ない。

\section{参考文献}

1）横浜市立大学医学部附属病院の医療事故に関する事 故調査委員会. 横浜市立大学医学部附属病院の医療 事故に関する事故調查委員会報告書. https://www. yokohama-cu.ac.jp/kaikaku/bk2/bk21.html

2）都立病産院医療事故予防対策推進委員会. 都立広尾 病院の医療事故に関する報告書. 一検証と提言一 1999. http://www.byouin.metro.tokyo.jp/hokoku/ hokoku/documents/hiroojiko.pdf.

3）牛島 謙. 医療事故公開基準。一ウェブを活用した バイオエシックス研究一. 四日市大学論集 2002;15： 147-157. 